\title{
A Teoria da Modernização Ecológica: uma avaliação crítica dos fundamentos teóricos
}

\author{
Alejandro Gabriel Olivieri
}

Nome do Curso: Doutorado em Sociologia

Data da defesa: 27 de maio de 2009

Orientador: Prof. Dr. Pedro Demo

\section{Resumo}

Ao se fazer uma análise teórica crítica dos fundamentos conceituais da Teoria da Modernização Ecológica, também se pretende aprofundar algumas noções teóricas relativas às continuidades e transformações institucionais da modernidade tardia, quando defrontadas com os desafios ambientais em curso, tal como são analisados pela Sociologia Ambiental atual.

Primeiramente, analisam-se os diferentes posicionamentos conceituais das principais tradições teóricas que formam parte da Sociologia Ambiental em relação a essas temáticas. A seguir, se realiza um diagnóstico dos conceitos-chave que sustentam o arcabouço teórico da Teoria da Modernização Ecológica, sublinhandose, especialmente, as suas abordagens originais e diferenciadas, se comparadas com as perspectivas das tradições teóricas clássicas da Sociologia Ambiental. Por último, destaca-se a relevância do debate teórico em curso entre a Teoria da Modernização Reflexiva, a Teoria da Sociedade do Risco e a Teoria da Modernização Ecológica, tanto para a Teoria Sociológica Contemporânea como para própria Sociologia Ambiental.

O que a Teoria da Modernização Ecológica considera significativo no debate conceitual com ambas as teorias é o 
reconhecimento explícito de que os problemas e desafios ambientais formam parte do núcleo central das mudanças estruturais em direção à modernidade tardia. $\mathrm{O}$ trabalho permite concluir que as formulações atuais da Teoria da Modernização Ecológica se desenvolveram gradualmente desde meados da década de 1980, embora a partir de diferentes clivagens e perspectivas analíticas. Isso leva a considerar que há uma variedade significativa de perspectivas ao interior dessa abordagem teórica e uma tentativa de aprimoramento conceitual que continua até hoje.

O trabalho também mostra que, desde a década de 1990, pode-se perceber uma re-conexão dos seus principais elementos conceituais com algumas das mais relevantes Teorias Sociológicas Contemporâneas, as quais, desde a mesma época, tentam elaborar novas abordagens conceituais para compreender a nova morfologia da modernidade emergente.

Palavras-chave: Teoria da Modernização Ecológica; Sociologia Ambiental; políticas ambientais. 